GRASAS Y ACEITES 71 (4)

October-December 2020, e385

ISSN-L: 0017-3495

https://doi.org/10.3989/gya.0803192

\title{
Production of lipids and natural antioxidants from passion fruit seeds
}

\author{
C.C. Reis ${ }^{\mathrm{a}}$, A.M.G.N. Mamede ${ }^{\mathrm{b}}$, A. Soares ${ }^{\mathrm{c}}$ and S.P. Freitas ${ }^{\mathrm{a}, \bigotimes}$ \\ ${ }^{a}$ Escola de Química - Universidade Federal do Rio de Janeiro - UFRJ. \\ ${ }^{\mathrm{b}}$ Instituto Federal de Educação, Ciência e Tecnologia da Bahia - IFBA - Campus Barreiras, BA, Brazil \\ ${ }^{\mathrm{c}}$ Embrapa Agroindústria de Alimentos - Rio de Janeiro - RJ, Brazil \\ ${ }^{\square}$ Corresponding author: freitasp@eq.ufrj.br
}

Submitted: 13 August 2019; Accepted: 29 November 2019; Published online: 27 October 2020

SUMMARY: The wild passion fruit species Passiflora setacea, Passiflora alata, and Passiflora tenuifila are native to the Brazilian biomass. The seed waste generated from the extraction of passion fruit juice contains functional polyunsaturated fatty acids and phenolic compounds. The aims of this study were to obtain lipids and natural antioxidants from passion fruit seeds. Passion seed oils were extracted using a lab-scale continuous press and their oxidative stability was evaluated using the Rancimat ${ }^{\circledR}$ method. Higher antioxidant extract capacity was observed when using an ethanol-water solution $(70: 30)$ at $45^{\circ} \mathrm{C}$. In these cases, the total phenolic contents expressed as gallic acid equivalents from $P$. setacea, $P$. alata, and $P$. tenuifila cakes were approximately 1800,600 and $900 \mathrm{mg} \cdot 100 \mathrm{~g}^{-1}$ of extract. Induction periods increased up to two-fold when adding these extracts to their respective seed oil. Therefore, passion fruit seed extract can contribute to increasing the oxidative stability of polyunsaturated oils.

KEYWORDS: Natural antioxidants; Passiflora alata; Passiflora setacea; Passiflora tenuifila; Phenolic compounds; Sustainable technology

RESUMEN: Producción de lípidos funcionales y antioxidantes naturales a partir de semillas de maracuyá. Las especies de maracuyá silvestre Passiflora setacea, Passiflora alata y Passiflora tenuifila son nativas de la biomasa brasileña. El desecho de semillas generado después de la extracción del jugo de maracuyá contiene ácidos grasos poliinsaturados funcionales y compuestos fenólicos. Los objetivos de este estudio fueron obtener lípidos y antioxidantes naturales de las semillas de maracuyá. Los aceites de semillas de la pasión se extrajeron usando una prensa continua a escala de laboratorio y su estabilidad oxidativa se evaluó usando el método Rancimat ${ }^{\circledR}$. Se observó una mayor capacidad antioxidante del extracto cuando se usó una solución de etanol-agua (70:30) a $45^{\circ} \mathrm{C}$. En estos casos, el contenido fenólico total expresado como equivalentes de ácido gálico de las tortas de P. setacea, P. alata y P. tenuifila fue de aproximadamente 1800,600 y $900 \mathrm{mg} \cdot 100 \mathrm{~g}^{-1}$ de extracto. Los períodos de inducción aumentaron hasta dos veces al agregar estos extractos a sus respectivos aceites de semillas. Por lo tanto, el extracto de semillas de maracuyá puede contribuir a aumentar la estabilidad oxidativa de los aceites poliinsaturados.

PALABRAS CLAVE: Antioxidantes naturales; Compuestos fenólicos; Passiflora alata; Passiflora setacea; Passiflora tenuifila; Tecnología sostenible

ORCID ID: Reis CC https://orcid.org/0000-0002-1942-6234, Mamede AMGN https://orcid.org/0000-0001-7154-6017, Soares A https://orcid.org/0000-0001-5796-2516, Freitas SP https://orcid.org/0000-0003-1490-9883

Citation/Cómo citar este artículo: Reis CC, Mamede AMGN, Soares A, Freitas SP. 2020. Production of lipids and natural antioxidants from passion fruit seeds. Grasas Aceites 71 (4), e385. https://doi.org/10.3989/gya.0803192

Copyright: (C2020 CSIC. This is an open-access article distributed under the terms of the Creative Commons Attribution 4.0 International (CC BY 4.0) License. 


\section{INTRODUCTION}

Passion fruits are native to America and grow in tropical and subtropical regions. About 150 native species are found in the Middle East and in northeastern Brazil, 60 of which are known to be edible (Dhawan et al., 2004; Bernacci et al., 2003; Cunha et al., 2002). Unfortunately, only two are currently commercially important, Passiflora edulis Sims f. flavicarpa Deg. (yellow passion fruit) and P. edulis f. edulis Sims (purple passion fruit) (Narain et al., 2012). However, other species display promising sensorial and functional characteristics and can be commercially exploited, such as $P$. setacea, $P$. alata and $P$. tenuifila, native Brazilian biome fruits, particularly in the Atlantic Rainforest, Cerrado and Caatinga biomasses.

Brazil is the largest passion fruit juice producer and consumer worldwide. In 2016, about 700 thousand tons of yellow passion fruit were produced (IBGE, 2016). At least $40 \%$ of the production is destined to the juice or pulp industries. Therefore, the passion fruit juice industry discards huge amounts of bagasse, composed mainly of husks and seeds that may still contain high amounts of bioactive compounds, particularly lipids and phenolics. Currently, these natural compounds are used as functional ingredients in food, contributing to the sustainable development of food and biomass production and processing.

Agro-industry pomace, such as peels and seeds, is of industrial interest due to its high contents in lipids, protein, fiber, sugar, vitamins, minerals and bioactive compounds, including phenolic compounds, phytosterols and carotenoids. In this case, these agroindustry residues become raw materials of interest to the chemical industry, particularly to the pharmaceutical, food and cosmetic sectors (Silva and Jorge, 2014). In addition, waste disposal is restricted by legal regulations. Thus, the processing of these materials has been shown to be technically and economically viable in several production chains (Lowe and Buckmaster, 1995).

Data reported in the literature indicate that passion fruit pomace contains phenolic compounds of significant industrial interest (Mirabella et al., 2014).

Passion fruit processing in the food industry discards up to $40 \%$ of the fruit, with seeds corresponding to $6-15 \%$ (Manica, 2005). Passion fruit oils are rich in monounsaturated and polyunsaturated fatty acids, mainly linoleic acid (C18: 2 n-6). According to Paula (2015), P. setacea BRS Pérola do Cerrado and $P$. alata BRS Sweet Honey lipids contain between 57 and $59 \%$ of this fatty acid. The fatty acid composition depends, among other factors, on the fruit species and climatic characteristics of the producing region.

Passion fruit seeds contain high amounts of piceatannol $\left(3,4,3^{\prime}, 5^{\prime}\right.$-tetrahydroxytans-stilbene) in their phenolic composition. Piceatannol is a resveratrol hydroxylate which presents strong antioxidant activity (Uchida-Maruki et al., 2015; Matsui et al., 2010). According to the reported data, the high piceatannol content in passion fruit seeds exerts positive effects on cultured dermal cells with respect to melanogenesis inhibition and collagen synthesis.

Due to the phytotherapeutical properties of native passion fruit species' pulp and leaves, Embrapa has been developing new passion fruit genotypes for classical genetic improvement, focusing on increasing fruit consumption, improving pleasant sensory characteristics, increasing field resistance and improving functional properties. Howerver, reported data on lipids from P. setacea, P. alata and P. tenuifila are rare. The main aims of this study were to obtain lipids and natural antioxidants from passion fruit seeds by applying sustainable technology.

\section{MATERIALS AND METHODS}

\subsection{Materials}

The passion fruit species (Passiflora alata BRS Doce Mel, Passiflora setacea BRS Peróla do Cerrado and Passiflora tenuifila) were cultivated in the experimental Embrapa Cerrados fields, located at Planaltina-DF/Brazil. The fruit was harvested when the skin color of the fruit reached about $20 \%$ yellow (between 40 and 60 days after inflorescence). The assays were carried out using homogenized seed lots between January and May, 2016. After fruit pulping, all the Passiflora seeds were stored at $-20^{\circ} \mathrm{C}$ until use. After thawing, the seeds were washed under tap water to remove the pulp and mucilage residues adhered to the seeds, followed by autoclaving at $120{ }^{\circ} \mathrm{C}$ for 20 minutes in order to reduce microbial loads.

\subsection{Seed drying kinetics}

Passion fruit seeds were dried in a convective dryer (Hauber - DMS-P) at $50{ }^{\circ} \mathrm{C}$ and 2-g samples were weighed at 30 minute intervals until constant weight over three successive weights. The drying temperature was optimized in previous experiments for $P$. alata and P. setacea seed drying (Paula, 2015). Physical air properties were monitored by the dew point of a Cole-Parmer Traceable ${ }^{\circledR}$ hygrometric thermometer. The room temperature of the air was $22.7 \pm 1{ }^{\circ} \mathrm{C}$ and humidity was approximately $50 \%$ and the temperature and humidity inside the dryer were $45 \pm 1{ }^{\circ} \mathrm{C}$ and $15 \%$, respectively. Drying was carried out in triplicate.

\subsection{Mass diffusion coefficient}

In order to estimate the effective water diffusivity $\left(D_{\text {eff }}\right)$ during seed drying, the dimensionless moisture (MR) and time $(\mathrm{t})$ data were adjusted by applying the second Fick diffusion law model (Eq. 1) in 
spherical coordinates, considering up to three term models of the infinite series solution, using the Statistica software (v13.0).

$$
\begin{aligned}
M r= & \frac{M-M s}{M o-M s}=\frac{9}{\pi^{2}} \sum_{n=0}^{\infty} \frac{1}{(2 n+1)^{2}} \\
& \exp \left(-\frac{(2 n+1)^{2} \pi^{2} D_{\text {eff }}}{r^{2}} t\right)
\end{aligned}
$$

\subsection{Grinding and seed oil extraction}

After drying, P. alata and P. setacea seeds were ground using a knife mill (Macron MA-048). This step was not necessary for $P$. tenuifila seeds, as they displayed a reduced mean diameter $(\mathrm{dp}<3 \mathrm{~mm})$. The seeds' moisture was adjusted between 12 and $15 \%$ in sealed dissectors containing distilled water, as recommended by Evangelista and Cermak, 2007. Crushed passion fruit seeds were processed in a continuous press (Oekotec - Germany, model CA59G), at room temperature of $22 \pm 1^{\circ} \mathrm{C}$ and compression ratio of 4.4 to obtain the first-extraction crude oil, which was then decanted for $24 \mathrm{~h}$ in a dark cabinet. A micropipette (Labmate Soft $1-5 \mu \mathrm{L}$ ) was used to separate the clarified oil. The clarified fraction was stored at $-18^{\circ} \mathrm{C}$ until analysis. To improve the extraction efficiency, the pressed cake was recycled and reprocessed at $30 \pm 2{ }^{\circ} \mathrm{C}$. At the end of extraction, the residual oil in pressed cake was recovered by Soxhlet using petroleun ether as solvent and the efficiency was then calculated. The defatted pressed cake was reserved for subsequently extraction of phenolic compounds.

\subsection{Phenolic compound extraction from pressed cake}

For phenolic compound extraction, the pressed cake was ground using a knife mill (Macron MA-048) coupled to a $1 \mathrm{~mm}$ diameter circular mesh sieve. The crushed sample, with particle diameter of less than $2 \mathrm{~mm}$, was then homogenized with ethanol at a 1:5 ratio (pressed cake:ethanolic solution).

The experimental design was carried out with three different aqueous-ethanol solutions selected from the preliminary test at the best selected extraction parameters of 30:70, 50:50 and 70:30 ethanol:water. The suspension was maintained in a heated bath at $45^{\circ} \mathrm{C}$ for 30 minutes at a stirring rate of $600 \mathrm{rpm}$. After extraction, the solids and soluble compounds were separated by vacuum filtration. The liquid phase containing the bioactive compounds was stored at $-18.0 \pm 0.5^{\circ} \mathrm{C}$ until analysis.

\subsection{Analytical methods}

Oxidative Stability: The oxidative stability of passion seed oils was determined using Rancimat ${ }^{\circledR}$ 743 (Metrohm, model 743) equipment, according to
EN 14112 , under a $10 \mathrm{~L} \cdot \mathrm{h}^{-1}$ flow at $110^{\circ} \mathrm{C}$, using $3 \mathrm{~g}$ of each oil sample, in duplicate. These test data were expressed as an induction period that represented the time interval until the sample reached a high oxidation level.

Antioxidant Capacity: The antioxidant capacity of passion seeds oils was determined according to a modified methodology developed by the Embrapa Tropical Agroindustry for fruit analysis (Rufino, 2007), which uses the DPPH (2,2-diphenyl-1-picryl-hidrazil) radical method, adapted for vegetable oils. The DPPH reagent was added at five different dilutions of the original oil in isopropyl alcohol, which then remained for one hour in the dark prior to a spectrophotometric analysis at $515 \mathrm{~nm}$ ((BelFotonix SP 1105). The Inhibitory Concentration (IC50 - mass necessary to reduce the initial concentration of the DPPH radical by $50 \%$ ) was determined from the absorbance readings.

The antioxidant capacity of the pressed cake was evaluated by the ABTS method, expressed as Trolox equivalents (TEAC) according to Re et al., (1999) and Rufino et al., (2007). The ABTS radical was chemically obtained by ABTS oxidation by potassium persulfate. Aliquots of $5 \mathrm{~mL}$ of the aqueous $7 \mathrm{mM}$ ABTS solutions were mixed with $88 \mu \mathrm{L}$ of $140 \mathrm{mM}$ potassium persulfate in amber bottles. The flasks were kept at room temperature for $14 \mathrm{~h}$ for complete reaction and radical stabilization, and a concentrated radical solution was obtained. The concentrated ABTS + solution was diluted in $95 \%$ ethanol to an absorbance of $0.700 \pm$ 0.020 at $734 \mathrm{~nm}$ (BelFotonix SP 1105) to form the test reagent.

Trolox ${ }^{\circledR}(300-2000 \mu \mathrm{M}$ in $95 \%$ ethanol) and the extracts were transferred to test tubes where they were left to react for 6 minutes with the diluted ABTS + solution at a 1:10 ratio at room temperature, followed by immediate spectrophotometric absorbance determinations at $734 \mathrm{~nm}$ (BelFotonix SP 1105). The discoloration of the mixed solution indicated that the antioxidant compounds in the extract inhibited the radical ABTS cations. A quantitative relationship between absorbance reduction at $734 \mathrm{~nm}$ and antioxidant concentrations present in the sample was noted. The results were expressed as $\mu$ mol Trolox $\cdot \mathrm{g}^{-1}$ of extract Total Phenolic (TP) Content: The total phenolic (TC) content of the pressed cake extract was determined by the spectrophotometric method proposed by Singleton and Rossi (1965), using the Folin-Ciocalteu reagent. This method is based on the oxi-reduction reaction, which forms a blue compound with the phenol. Briefly, $0.5 \mathrm{~mL}$ of each sample was mixed with $2.5 \mathrm{~mL}$ of the $10 \%$ Folin-Ciocalteu reagent and vortexed for $2 \mathrm{~min}$. After homogenization, $2 \mathrm{~mL}$ of a saturated sodium carbonate solution $(7.5 \%)$ were added. The solution was then incubated for $15 \mathrm{~min}$ at $50{ }^{\circ} \mathrm{C}$ in a water bath, and immediately cooled in an ice bath 
for 30 seconds. The absorbance of the mixture was determined at $760 \mathrm{~nm}$ using a spectrophotometer (BelFotonix SP 1105). Phenolic compound quantification was performed using a gallic acid calibration curve. The results were expressed as $\mathrm{mg}$ gallic acid equivalent per $100 \mathrm{~g}$ of sample (GAE.100.g ${ }^{-1}$ ).

\subsection{Addition of phenolic extract to passion fruit seed oils}

The extracts obtained from the passion fruit seeds P. alata, P. setacea and P. tenuifila in 70:30 ethanolwater solutions were selected to increase the oxidative stability of their respective oils. To maintain bioactive properties, the solvents were removed from the extracts by forced convection at an air temperature of $21^{\circ} \mathrm{C}$.

The dried extracts were mixed with passion fruit seed oils at $10 \%$ mass/mass ratio, according to preliminary tests. To evaluate the oxidative stability of the mixtures, $3 \mathrm{~g}$ of each sample were then transferred to a Rancimat reaction tube, and the analyses were performed in duplicate using an air flow at $10 \mathrm{~L} . \mathrm{h}^{-1}$ and $110^{\circ} \mathrm{C}$.

\subsection{Statistical analyses}

All analytical determinations were carried out at least in triplicate, except for oxidative stability trials. An analysis of variance (ANOVA) followed by Fisher's LSD test was performed using the Statistica ${ }^{\circledR}$ V.13.0 software.

\section{RESULTS AND DISCUSSION}

\subsection{Seed drying kinetics}

The estimated drying rate parameters and corresponding $\mathrm{R}$-squared results are presented in Table 1 . In addition, kinetic curves at $50{ }^{\circ} \mathrm{C}$ which fitted the experimental data for passion fruit seed drying by Fick's second law are displayed in Figure 1.

The following equations were used to determine P. $\operatorname{alata}($ Eq. 1.a), P. setacea (Eq1.b) and P. tenuifila (Eq. 1.c):

TABLE 1. Effective diffusion coefficient $\left(\mathrm{D}_{\text {eff }}\right)$ during mass transport in the drying process of passion fruit seeds

\begin{tabular}{lccc}
\hline Sample & $\begin{array}{c}\text { Average } \\
\text { radius (mm) }\end{array}$ & $\mathbf{D}_{\mathbf{e f f}}\left(\mathbf{m}^{\mathbf{2}} \mathbf{.} \mathbf{- 1}^{\mathbf{1}}\right) \times \mathbf{1 0} \mathbf{1 0}^{\mathbf{1 0}}$ & $\mathbf{R}^{\mathbf{2}^{*}}$ \\
\hline Passiflora alata & $1.9 \pm 0.5$ & $1.14 \pm 0.82$ & 0.98 \\
Passiflora setacea & $1.3 \pm 0.5$ & $0.82 \pm 0.87$ & 0.98 \\
Passiflora tenuifila & $1.3 \pm 0.4$ & $0.83 \pm 0.68$ & 0.98 \\
\hline
\end{tabular}

$* \mathrm{R}^{2}$ regression coefficient. Each point represents mean value of three replicates $\pm \mathrm{SD}$ value

$$
M r=\frac{9}{\pi^{2}}\left(\begin{array}{l}
\left(\exp \left(-\pi^{2} * 3.06 * 10^{-9} * t\right)\right)+\frac{1}{9} \\
* \exp \left(-9 \pi^{2} * 3.06 * 10^{-9} * t\right)+\frac{1}{25} \\
* \exp \left(-25 \pi^{2} * 3.06 * 10^{-9} * t\right)
\end{array}\right)[1 . a]
$$$$
M r=\frac{9}{\pi^{2}}\left(\begin{array}{l}
\left(\exp \left(-\pi^{2} * 4.62 * 10^{-9} * t\right)\right)+\frac{1}{9} \\
* \exp \left(-9 \pi^{2} * 4.62 * 10^{-9} * t\right)+\frac{1}{25} \\
* \exp \left(-25 \pi^{2} * 4.62 * 10^{-9} * t\right)
\end{array}\right)[1 . b]
$$$$
M r=\frac{9}{\pi^{2}}\left(\begin{array}{l}
\left(\exp \left(-\pi^{2} * 4.66 * 10^{-9} * t\right)\right)+\frac{1}{9} \\
* \exp \left(-9 \pi^{2} * 4.66 * 10^{-9} * t\right)+\frac{1}{25} \\
* \exp \left(-25 \pi^{2} * 4.66 * 10^{-9} * t\right)
\end{array}\right)[1 . c]
$$

The diffusion coefficient for $P$. alata seeds was higher than the other two assessed species. It was possible to estimate the drying time of the passion fruit seeds from the fitted equation, in order to achieve the best moisture for pressing passion fruits seeds between 10 and $15 \%$.

\subsection{Oil extraction}

The oil contents of dried passion fruit seeds were 19,16 and $23 \%$ for $P$. alata, $P$. setace a and $P$. tenuifila, respectively (Table 2). Paula (2015) reported a lipid content of 22.5 and $32.2 \%$ for $P$. alata and $P$. setacea, respectively. This difference may be due to seasonality effects, particle size and moisture. The efficiencies of the continuous oil extraction process, calculated by the ratio of the oil mass obtained for the total oil in the seeds, were $57 \%$ to $67 \%$, as displayed in Table 2.

These results are typical of continuous oil extraction from lignin-rich seeds (up to $40 \%$ in dry matter and lipid content of less than $30 \%$ ). In addition, the extraction yield for $P$. setacea was lower, in contrast to the data reported by Paula (2015), possibly due to the harvest season. The overall yield after heated cake pressing was increased by about $10 \%$. According to reported data, cold-pressed oils require no further refinement and can be consumed after simple decantation, presenting superior sensory characteristics and nutritional qualities when compared to hotpressed oils (Emir, Gunes and Yilmaza, 2014). 


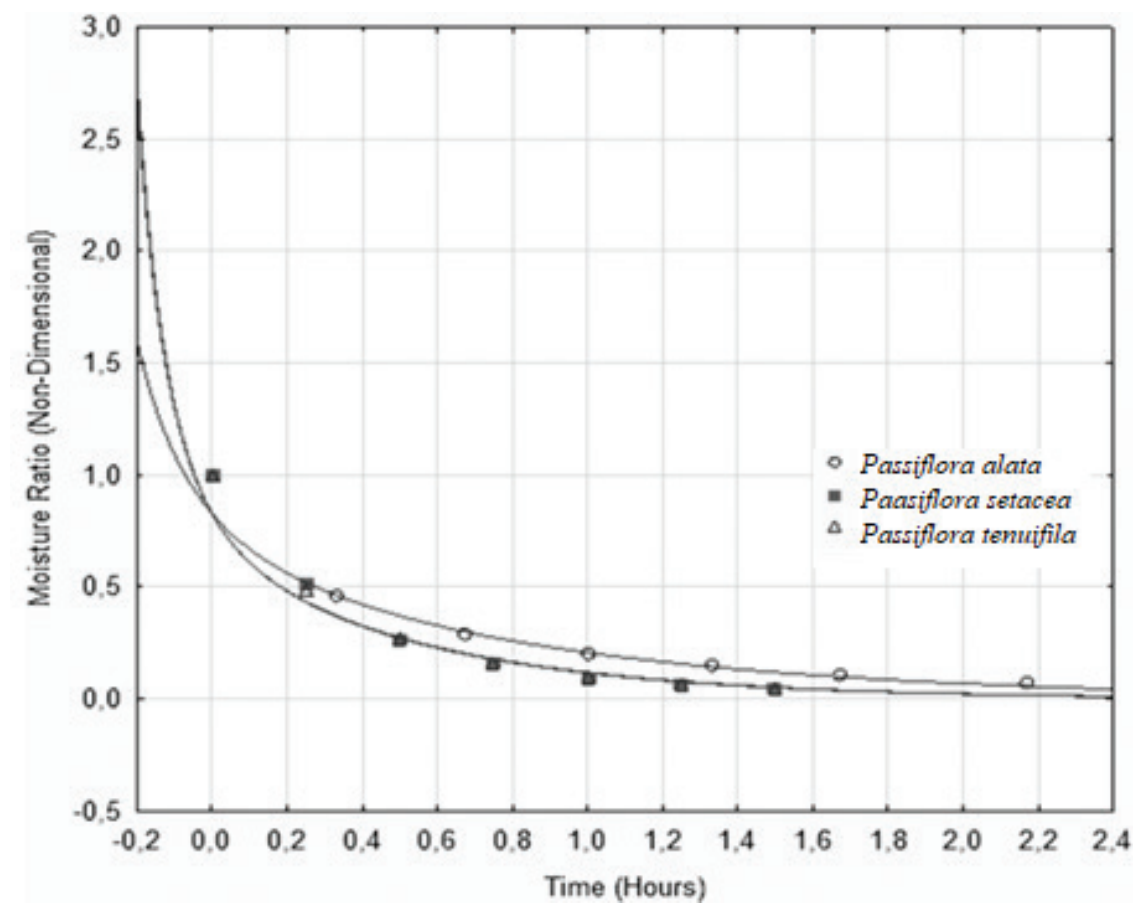

FIGURE 1. Drying curves of the three species of passion fruit seeds. The experimental data are points and the fit model is a continuous line. The P. setacea and P. tenuifila curves intersect.

TABLE 2. Moisture, oil content and oil extraction yield from cold-pressed passion fruit seeds

\begin{tabular}{lccc}
\hline Sample & $\begin{array}{c}\text { Moisture after } \\
\text { drying (\%) }\end{array}$ & $\begin{array}{c}\text { Oil content } \\
(\%)\end{array}$ & $\begin{array}{c}\text { Oil Extraction } \\
\text { yield }^{\mathbf{1}}(\mathbf{\%})\end{array}$ \\
\hline Passiflora alata & $15.0 \pm 0.6^{\mathrm{a}}$ & $19 \pm 1^{\mathrm{b}}$ & $67 \pm 1^{\mathrm{a}}$ \\
Passiflora setacea & $11.0 \pm 0.1^{\mathrm{b}}$ & $16 \pm 1^{\mathrm{c}}$ & $57 \pm 1^{\mathrm{c}}$ \\
Passiflora tenuifila & $10.0 \pm 0.2^{\mathrm{c}}$ & $23 \pm 1^{\mathrm{a}}$ & $63 \pm 1^{\mathrm{b}}$
\end{tabular}

${ }^{1}$ The yield of the oil extraction is the ratio of the oil extracted in cold pressing and the total oil in the sample.

a,b,c, Different letters in the same column indicate significant differences $(\mathrm{p}<0.05)$ according to ANOVA one way Fisher LSD test.

Each point represents the mean value of two replicates \pm SD value.

\subsection{Oxidative stability and antioxidant capacity}

As displayed in Table 3, the induction periods (IP) for P. setacea and P. tenuifila seed oils at $110^{\circ} \mathrm{C}$ were $7.32 \mathrm{~h}$ and $6.87 \mathrm{~h}$, respectively, which were typical IP for passion fruit seed oils (Paula et al., 2015). However, P. alata presented a lower IP 50\% (3.53 h), which could be explained by the lower oleic acid and higher linoleic acid contents in P. alata seed oil (Santana et al., 2015). Due to the two double bonds present in linoleic acid, this acid is 40 times more unstable than oleic acid, which contains only one double bond (Damodaran and Parkin, 2017).

The $\mathrm{IC}_{50}$, defined as the amount of antioxidant required to reduce DPPH concentrations by $50 \%$,
TABLE 3. Oxidative stability and antioxidant capacity by DPPH inhibition of Passiflora seed oils

\begin{tabular}{lccc}
\hline Samples & $\begin{array}{c}\text { Induction } \\
\text { period(h) }\end{array}$ & $\begin{array}{c}\text { DPPH } \\
\text { inhibition (\%) }\end{array}$ & $\begin{array}{c}\text { IC50 mg oil. } \\
\text { mg DPPH }\end{array}$ \\
\hline Passiflora alata & $3.52 \pm 0.14^{\mathrm{c}}$ & $43 \pm 1^{\mathrm{b}}$ & $1.09 \pm 0.24^{\mathrm{b}}$ \\
Passiflora setacea & $7.32 \pm 0.04^{\mathrm{a}}$ & $53 \pm 3^{\mathrm{a}}$ & $1.09 \pm 0.03^{\mathrm{b}}$ \\
Passiflora tenuifila & $6.87 \pm 0.10^{\mathrm{b}}$ & $24 \pm 3^{\mathrm{c}}$ & $2.60 \pm 0.05^{\mathrm{a}}$
\end{tabular}

a,b,c, Different letters in the same column indicate significant differences $(\mathrm{p}<0.05)$ according to ANOVA one way Fisher LSD test.

Each point represents mean value of three replicates \pm SD value.

is considered a good antioxidant capacity measure (inversely proportional). Regarding DPPH results, the oil from $P$. setacea seeds presented the highest antioxidant capacity, followed by $P$. alata and $P$. tenuifila. These values were consistent with the literature data reported by Santana et al., (2015), and could be explained due to the higher vitamin $\mathrm{E}$ content in $P$. setacea $\left(215.3 \mathrm{mg} \cdot 100 \mathrm{~g}^{-1}\right)$ and $P$. alata $\left(114.8 \mathrm{mg} \cdot 100 \mathrm{~g}^{-1}\right)$ seed oil compared to $P$. tenuifila seed oil $\left(80 \mathrm{mg} \cdot 100 \mathrm{~g}^{-1}\right)$.

\subsection{Pressed cake total phenolic (TP) content and antioxidant capacity (TEAC)}

The most efficient solid-liquid extraction of bioactive compounds from the pressed cake was achieved using 70:30 ethanol-water solutions at 
TABLE 4. Total phenolic (TP) contents and antioxidant capacity (TEAC) of the ethanolic extract from pressed cake

\begin{tabular}{lccc}
\hline Sample & $\begin{array}{c}\text { ethanol: } \\
\text { water ratio }\end{array}$ & $\begin{array}{c}\text { Total } \\
\text { phenolic }\end{array}$ & $\begin{array}{c}\text { TEAC }(\boldsymbol{\mu m o l} \\
{\text { Trolox} \cdot \mathbf{g}^{-1}}^{-1}\end{array}$ \\
\hline $\begin{array}{lccc}\text { Passiflora } \\
\text { alata }\end{array}$ & $30: 70$ & $293.5 \pm 41.2^{\mathrm{f}}$ & $242.96 \pm 18.0^{\mathrm{g}}$ \\
& $50: 50$ & $477.2 \pm 35.7^{\mathrm{e}}$ & $568.24 \pm 107.8^{\mathrm{ef}}$ \\
Passiflora & $70: 30$ & $596.9 \pm 10.9^{\mathrm{d}}$ & $670.19 \pm 95.5^{\mathrm{de}}$ \\
setacea & $50: 70$ & $220.5 \pm 6.0^{\mathrm{g}}$ & $200.03 \pm 3.06^{\mathrm{g}}$ \\
& $70: 30$ & $1159.9 \pm 29.9^{\mathrm{b}}$ & $1032.64 \pm 121.4^{\mathrm{b}}$ \\
& $30: 70$ & $445.9 \pm 28.2^{\mathrm{e}}$ & $451.27 \pm 23.4^{\mathrm{f}}$ \\
Passiflora & $50: 50$ & $886.7 \pm 87.2^{\mathrm{c}}$ & $739.88 \pm 86.3^{\mathrm{d}}$ \\
& $70: 30$ & $909.0 \pm 25.1^{\mathrm{c}}$ & $878.04 \pm 51.5^{\mathrm{c}}$ \\
\hline
\end{tabular}

$\overline{\mathrm{a}, \mathrm{b}, \mathrm{c}, \mathrm{d}, \mathrm{e}, \mathrm{f}, \mathrm{g}}$ Different letters in the same column indicate significant differences $(\mathrm{p}<0.05)$ according to the ANOVA one way Fisher LSD test.

Each point represents the mean value of three replicates \pm SD value.

$45^{\circ} \mathrm{C}$. This was probably due to the greater solubility of the polar compounds in the passion fruit seed cake in this aqueous and ethanolic solution. The highest values for total TP contents and TEAC for the pressed cake extracts are displayed in Table 4. For the selected experimental conditions, the ethanolic $P$. setacea extract presented higher TP contents and TEAC when compared to the other species.

Total phenols from P. setacea, P. alata, and P. tenuifila cakes were approximately 1800,600 and $900 \mathrm{mg}$ GAE $100 \mathrm{~g}^{-1}$ of extract, respectively. The TP of the extract obtained at a 70:30 ratio from the $P$. setacea cake was 3- and 2-fold higher than the P. alata and $P$. tenuifila extracts, respectively (Table 4 ). A strong positive Pearson correlation $(\mathrm{R}=0.97)$ with antioxidant activity was observed, since the results for the antioxidant capacity in the same experimental conditions for the P. setacea cake were 2.3- and 1.8-fold higher than for $P$. alata and $P$. tenuifila, respectively.

According to Vasco et al., (2008) the ethanolic extracts obtained in the present study from pressed $P$. alata and $P$. tenuifila cakes can be treated as medium phenolic contents, while the extracts obtained at 50:50 and 70:30 ethanol:water ratios from pressed $P$. setacea cake are treated as high phenolic contents.

\section{CONCLUSIONS}

P. setacea, $P$. alata, and P. tenuifila passion seed oils obtained by pressing presented high quality indexes, probably due to the presence of phenolic compounds in the cake. Furthermore, it was possible to enhance the oxidative stability of all samples by adding $10 \%$ of the ethanolic extract obtained from defatted cake, which are rich in natural antioxidants. Future studies should be conducted to evaluate the best ethanolic extract to oil ratio.

\section{ACKNOWLEDGMENTS}

The authors would like to thank the Federal University of Rio de Janeiro (UFRJ/EQ), Embrapa Cerrados, Embrapa Food Technology and Brazilian National Research Council $(\mathrm{CNPq})$ for supporting this study.

\section{REFERENCES}

American Oil Chemists' Society. 2004. Official methods and recommended practices of the American Oil Chemists' Society. 4th ed. Champaign, USA: A.O.C.S.

Bernacci LC, Meletti LMM, Soares-Scott MD. 2003. Maracujádoce: o autor, a obra e a data da publicação de Passiflora alata (Passifloraceae). Rev. Bras. Frutic. Jaboticabal 25 (2), 355-356, agosto 2003. https://doi.org/10.1590/ S0100-29452003000200046

Cunha MAP, Barbosa LV, Junqueira NTV. 2002. Espécies de maracujazeiro. In: LIMA, A. A. (Ed.). Maracujá Produção: Aspectos Técnicos. Brasília: Embrapa Informação Tecnológica, 104p. (Frutas do Brasil; 15).

Damodaran S, Parkin KL. 2017. Fennema's food chemistry. CRC press.

Dhawan K, Dhawan S, Sharma A. 2004. Passiflora: A review update. J. Ethnopharmacol. 94 (1), 1-23. https://doi.org/ 10.1016/j.jep.2004.02.023

Emir DD, Güneșer O, Yilmaz E. 2014. Cold pressed poppy seed oils: sensory properties, aromatic profiles and consumer preferences. Grasas Aceites 65 (3), e029. http://doi. org/10.3989/gya.109213

Evangelista RL, Cermak SC. 2007. Full-Press Oil Extraction of Cuphea (PSR23) Seeds. J. Am. Oil. Chem. Soc. 84, 1169. https://doi.org/10.1007/s11746-007-1142-5

IBGE. 2016. Produção Agrícola Municipal: Culturas temporárias e permanentes. Retrieved January 5, 2018, from https://www. ibge.gov.br/estatisticas-novoportal/economicas/agriculturae-pecuaria/9117-producao-agricola-municipal-culturastemporarias-e-permanentes.html?\&t=resultados. Accessed January 5,2018

Lowe ED, Buckmaster DR. 1995. Dewatering makes big difference in compost strategies, Biocycle, v. 36, p. 78-82

Narain N, Almeida JDN, Galvão MDS, Madruga MS, Brito ESD. 2004. Volatile compounds in passion fruit (Passiflora edulis forma Flavicarpa) and yellow mombin (Spondias mombin L.) fruits obtained by dynamic headspace technique. Food Sci. Tech-Brazil 24 (2), 212-216. https://doi. org/10.1590/S0101-20612004000200009

Manica I. 2005. Maracujá-doce: tecnologia de produção, póscolheita, mercado. Porto Alegre: Cinco Continentes. 198 p.

Matsui Y, Sugiyama K, Kamei M, Takahashi T, Suzuki T, Katagata Y, Ito T. 2010. Extract of passion fruit (Passiflora edulis) seed containing high amounts of piceatannol inhibits melanogenesis and promotes collagen synthesis. J. Agric. Food Chem. 58 (20), 11112-11118. https://doi.org/10.1021/ jf102650d

Mirabella N, Castellani V, Sala S. 2014. Current options for the valorization of food manufacturing waste: A review. $J$. Clean. Prod. 65, 28-41. https://doi.org/10.1016/j.jclepro. 2013.10.051

Paula RCM de. 2015. Óleo de semente de maracujá (Passiflora setacea BRS Pérola do Cerrado e Passiflora alata BRS Doce Mel): Propriedades químicas e efeito do processamento no perfil decompostos voláteis. DS Thesis, Escola de Química, Universidade Federal do Rio de Janeiro, Brasil.

Re R, Pellegrini N, Proteggente A, Pannala A, Yang M, RiceEvans C. 1999. Antioxidant activity applying an improved ABTS radical cation decolorization assay $26(98), 1231-$ 1237. https://doi.org/10.1016/S0891-5849(98)00315-3

Rufino MSM, Alves RE, de Brito ES, Morais SM, Sampaio CG, Pérez-Jiménez J, Calixto FDS. 2007. Metodologia Científica: Determinação da atividade antioxidante total em frutas pela captura do radical livre DPPH - A report 
to the expert group on antioxidant activity. Occasional publication No. 128. Ministério Da Agricultura, Pecuária e Abastecimento, Fortaleza, Ceará 23 (2), 1-4

Santana FC, Shinagawa FB, Araujo ES, Costa AM, ManciniFilho J. 2015. Chemical Composition and Antioxidant Capacity of Brazilian Passiflora Seed Oils. J. Food Sc. 80 (12), C2647-C2654. https://doi.org/10.1111/1750-3841. 13102

Silva AC, Jorge N. 2014. Bioactive compounds of the lipid fractions of agro-industrial waste. Food Res. Int. 66, 493-500. https://doi.org/10.1016/j.foodres.2014.10.025
Singleton VL, Rossi JA. 1965. Colorimetry of total phenolics with phosphomolybdic-phosphotungstic acid reagents. Am. J. Enol. Vitic. 16, 144-168.

Uchida-Maruki H, Inagaki $\mathrm{H}$, Ito $\mathrm{R}$, Kurita I, Sai M, Ito T. 2015. Piceatannol Lowers the Blood Glucose Level in Diabetic Mice. Biol. Pharm. Bull. 38 (4), 629-633. https:// doi.org/10.1248/bpb.b15-00009

Vasco C, Ruales J, Kamal-Eldin A. 2008. Total phenolic compounds and antioxidant capacities of major fruits from Ecuador. Food Chem. 111 (4), 816-823. https://doi.org/ 10.1016/j.foodchem.2008.04.054 